\title{
PERBANDINGAN TEORI ASURANSI: STUDI PERBANDINGAN TEORI EKONOMI TAQIYYUDDÎN AL-NABANI DAN THOMAS ROBERT MALTUS
}

\author{
Deni Kamaludin Yusup \\ Fakultas Syariah dan Hukum UIN Sunan Gunung Djati Bandung \\ E-mail:dk_yusup@yahoo.com
}

\begin{abstract}
Insurance could be understood as a guarantee or a trade given the insurer (insurance company) to the insured for the risk of loss specified in the agreement (polis) with the obligations of the insured have should pay a premium to the insurer (insurance company). In modern times, the insurance is one of profitable transactions, because many people are starting to realize that the insurance is very important thing. This article will explain some of the theories about the insurance from the perspective of Shari'ah and conventional which focused on the economic theory presented by Taqiyyuddîn Al-Nabani and Thomas Robert Maltus. From this article, we are expected to understand about the differences between the concepts of insurance based on shariah and conventional perspektive clearly and thoroughly.
\end{abstract}

\begin{abstract}
Abstrak
Asuransi dapat pula difahami sebagai suatu jaminan atau perdagangan yang diberikan pihak penanggung (Perusahaan Asuransi) kepada pihak tertanggung untuk resiko kerugian yang ditetapkan dalam surat perjanjian (polis), dengan kewajiban pihak tertanggung harus membayar sejumlah premi kepada pihak penanggung (Perusahaan Asuransi). Di jaman modern ini, asuransi merupakan salah satu bentuk transaksi yang menguntungkan, karena banyak orang yang mulai menyadari bahwa asuransi termasuk hal yang sangat penting. Berkenaan dengan hal di atas, tulisan ini akan menjelaskan beberapa teori tentang asuransi yang dilihat dari perspektif syari'ah dan konvensional yang difokuskan pada teori ekonomi Taqiyyuddîn Al-Nabani dan Thomas Robert Maltus. Dari tulisan ini diharapkan adanya kejelasan tentang perbedaan konsep asuransi yang berbasis syari'ah dan konvensional.
\end{abstract}

Kata Kunci:

Ekonomi, Asuransi, Islam, Konvensional

\section{A. Pendahuluan}

Asuransi tidak hanya dikenal dalam sistem ekonomi konvensional, tetapi juga dikenal dalam sistem ekonomi Islam. Dalam ekonomi Islam dikenal Takaful, yaitu salah satu lembaga keuangan syari'ah non bank yang bergerak dalam bidang jasa penjaminan atau pertanggungan resiko. Karenanya, Asuransi Takaful dapat dilihat sebagai lembaga keuangan atau perusahaan jasa keuangan non bank yang beroperasi dalam bidang pertanggungan atau penjaminan resiko kepada para nasabahnya.

Dari pengertian di atas, Asuransi Takaful berarti diposisikan sebagai pihak penanggung atau penjamin atas segala resiko keru- gian, kerusakan, kehilangan atau kematian yang dialami oleh nasabah (pihak tertanggung). Dalam hal ini, si tertanggung mengikat perjanjian (penjaminan resiko) dengan si penanggung atas barang atau harta, jiwa dan sebagainya berdasarkan prinsip bagi hasil berdasarkan pola pembagian keuntungan dan kerugian (profit and loss sharing) yang disepakati oleh kedua belah pihak. ${ }^{1}$

Berkenaan dengan hal di atas, tulisan ini akan menjelaskan beberapa teori tentang asuransi yang dilihat dari perspektif syari'ah dan konvensional yang difokuskan pada

${ }^{1}$ A. Djazuli dan Yadi Janwari, Lembaga-lembaga Perekonomian Umat (Jakarta: Rajawali Press, 2002). 
teori ekonomi Taqiyyuddîn Al-Nabani dan Thomas Robert Maltus. Dari tulisan ini diharapkan adanya kejelasan tentang perbedaan konsep asuransi yang berbasis syari'ah dan konvensional.

\section{B. Gambaran Umum Tentang Asuransi \\ 1. Pengertian Asuransi}

Dari segi bahasa, asuransi berasal dari bahasa Inggris insurance dan bahasa Belanda verzekering atau asurantie yang berarti pertanggungan atau penjaminan. ${ }^{2}$ Dalam perspektif ekonomi Islam, asuransi dikenal dengan istilah takaful yang berasal dari bahasa Arab yakni takafala - yatakafulu - takaful yang berarti saling menanggung atau saling menjamin. ${ }^{3}$ Asuransi dapat diartikan sebagai perjanjian yang berkaitan dengan pertanggungan atau penjaminan atas resiko kerugian tertentu.

Dalam fatwa Dewan Syariah Nasional (DSN-MUI) Asuransi didefinisikan sebagai sebuah usaha saling melindungi dan tolong menolong di antara sejumlah orang melalui investasi dalam bentuk aset dan/atau tabarru' yang memberikan pola pengembalian untuk menghadapi risiko tertentu melalui akad yang sesuai dengan syariah. ${ }^{4}$ Asuransi dalam Islam dipahami sebagi sebuah sistem di mana para peserta mendonasikan sebagian atau seluruh kontribusi atau premi yang mereka bayar untuk digunakan membayar klaim atas musibah yang dialami oleh sebagian peserta. Proses hubungan peserta dan perusahaan dalam mekanisme pertanggungan pada Asuransi Syariah adalah sharing of risk atau "saling menanggung risiko". Apabila terjadi musibah, maka semua peserta Asuransi Syariah saling menanggung. Dengan demikian, tidak terjadi transfer risiko (transfer of risk atau "memindahkan risiko") dari peserta ke perusahaan seperti pada asuransi konvensional.

Asuransi juga dapat pula difahami sebagai suatu jaminan atau perdagangan yang

\footnotetext{
${ }^{2}$ Wirjono Prodjodikoro, Hukum Asuransi di Indonesia (Jakarta: PT. Pembimbing Masa. 1972), hlm. 3-5.

${ }^{3}$ Yadi Janwari, Diktat Perkuliahan Asuransi Takaful (Bandung: Fakultas Syari'ah IAIN SGD. 2000), hlm. 3.

${ }^{4}$ Fatwa DSN MUI No 21/DSN-MUI/X/2001
}

diberikan pihak penanggung (kantor asuransi) kepada pihak tertanggung untuk resiko kerugian yang ditetapkan dalam surat perjanjian (polis) apabila terjadi kebakaran, kecurian, kerusakan dan sebagainya ataupun mengenai kehilangan jiwa (kematian) atau kecelakaan lainnya, dengan yang tertanggung membayar premi sebanyak yang ditentukan kepada penanggung tiap-tiap bulan. ${ }^{5}$

Sebagaimana disebutkan dalam Pasal 1 (ayat 1) Undang-Undang No. 2/1992 tentang Perasuransian, yang dimaksud dengan asuransi adalah:
"Suatu perjanjian antara dua pihak atau lebih; pihak penanggung mengikatkan diri kepada tertanggung dengan meneri- ma sejumlah uang premi asuransi untuk memberikan penggantian kepada ter- tanggung karena kerugian, kerusakan atau kehilangan keuntungan atau tang- gung jawab hukum kepada pihak ketiga yang timbul dari peristiwa yang tidak pasti untuk memberikan suatu pemba- yaran didasarkan atas meninggalnya atau hidupnya seseorang yang diper- tanggungkan". ${ }^{6}$

Selain itu, pengertian asuransi dijelaskan pula dalam Pasal 246 ayat 74 Kitab UndangUndang Hukum Dagang (KUHD) disebutkan bahwa:

\begin{abstract}
"Asuransi atau pertanggungan adalah suatu perjanjian; yang dengannya seorang penanggung mengikatkan dirinya kepada seorang tertanggung, dengan menerima premi, untuk memberikan penggantian kepadanya karena suatu kerugian, kerusakan atau kehilangan keuntungan yang diharapkan, yang mungkin akan dideritanya karena suatu peristiwa yang tidak pasti atau tentu."
\end{abstract}

\section{Dasar Hukum Asuransi}

Dasar hukum asuransi didasarkan kepada beberapa aspek berikut:

${ }^{5}$ M. Ali Hassan, Masail Fiqhiyah: Zakat, Pajak, Asuransi dan Lembaga Keuangan (Jakarta: PT. Raja Grafindo. 1997), hlm. 57.

${ }^{6}$ Lihat Pasal 1 Ayat (1) Undang-undang Nomor 2/1992 tentang Perasuransian. 
a. Landasan Syari'ah

Quran Surat Al-Maidah: 2 yang berbunyi: "tolong-menolonglah kamu dalam kebajikan dan jangan tolong-menolong dalam berbuat dosa dan permusuhan".

Hadits Nabi yang diriwayatkan oleh Imam Bukhari dan Muslim yang berbunyi: "Setiap orang dari kamu adalah pemikul tanggung jawab (pemimpin), dan setiap kamu akan bertanggung jawab terhadap orang-orang yang berada di bawah tanggung jawab kamu".

\section{b. Landasan Filosofis}

Tradisi ijtihad bersamaan dengan perubahan sosial dan hukum Islam. ljtihad menjadi media bagi perumusan norma-norma hukum Islam (istinbath al-ahkâm) secara sistematis berikut pembentukan pranata-pranatanya, termasuk asuransi syar'ah melalui penalaran akal terhadap nash.?

\section{c. Landasan Sosiologis}

Secara mikro, berdirinya Asuransi Takaful lebih mengandalkan potensi modal dalam negeri (capital domestic), di mana pihak swasta berperan investasi dalam struktur dan manajemen lembaga keuangan syari'ah. Sedangkan secara makro, tingkat partisipasi ekonomi pasar global dalam pembangunan ekonomi di Indonesia belum memberi perhatian bagi pembangunan ekonomi Islam. ${ }^{8}$

d. Landasan Yuridis (Dalam Sistem Hukum Indonesia)

1) Pasal 1774 KUHD yang berbunyi: "Suatu persetujuan untung-untungan (kansovereenkomst) adalah suatu perbuatan yang hasilnya mengenai untung ruginya, baik bagi semua pihak maupun bagi sementara pihak, bergantung kepada suatu kejadian yang belum tentu".

\footnotetext{
${ }^{7}$ Wahbah Zuhaili, Ushul Fiqh Al-Islami (Damaskus: Dar al-Fikr. 1986), hlm. 1039.

${ }^{8}$ Suroso Imam Zadjuli, Kelembagaan Ekonomi Islam Dalam Perspektif Islam: Kajian Kritis Terhadap Kelembagaan Konvensional, makalah dalam "Seminar dan Lokakarya Kurikulum dan Silabus Ekonomi Islam" untuk Program Pascasarjana Universitas Islam Negeri (UIN) Syarif Hidayatullah Jakarta, Juni 2003, hlm. 9-10.
}

2) Persetujuan Asuransi diatur dalam:
a) Buku I, Bab IX: Asuransi secara umum;
b) Buku II, Bab X: Asuransi Kebakaran, Asuransi Pertanian dan Asuransi Jiwa;
c) Buku II, Bab IX : Asuransi Laut, Asuransi Bahaya Perbudakan;
d) Buku II, Bab X: Asuransi Pengang- kutan Darat, Sungai dan Perairan Daratan

3) Di luar KUHD, peraturan tentang asuransi diatur pula dalam ketentuanketentuan berikut:
a) UU No. 33/1964 tentang Dana Kece- lakaan Penumpang
b) UU No. 34/1964 tentang Dana Kece- lakaan Lalu Lintas Jalan
c) UU No. 10/1963 tentang Tabungan dan Asuransi Pegawai Negeri (Tas- pen)
d) UU No. 4/1965 tentang Pendirian PN. Asuransi Benda Sraya
e) PP No. 1/1971 tentang Penyertaan Modal Negara RI untuk Pendirian Perusahaan Perseroan dalam bi- dang perasuransian kredit
f) UU No. 2/1992 tentang Usaha Pera- suransian

4) Lembaga Asuransi Takaful di Indonesia berdiri dalam bentuk holding Company yang secara yuridis telah memperoleh status badan hukum dan persetujuan dari Departemen Kehakiman Republik Indonesia nomor C2-18.286.MT.01/01.Th.94 tertanggal 14 Desember 1994. Izin operasional 4 tertanggal 1 Juni 1995 dengan Akta Notaris Yudo Paripurno, SH tanggal 5 Mei 1994.

\section{Perbedaan Pendapat Para Ulama Mengenai Hukum Asuransi}

Para ulama berbeda pendapat tentang status hukum asuransi. Perbedaan tersebut disebabkan oleh tiga hal: Pertama, formulasi kaidah (al-ta'sîs) yaitu ada yang berpegang kepada pemahaman uslub/dalil syara' dan ada pula yang berpegang kepada maslahmasalah cabang (furu'); Kedua, metodologi (manhaj) yaitu rumusan metode hukum dilakukan secara induktif dan secara deduktif. 
Hal ini akan berimplikasi pada adanya dua corak kaidah, yakni kaidah ushul dan kaidah fiqh; Ketiga, aspek pemikiran yang dipakai para ulama dalam berijtihad. Ada yang berpegang kepada nash dan ada yang pula berpegang kepada ra'yu. ${ }^{9}$

Ketika muncul Asuransi Takaful yang menggunakan prinsip syari'ah, sebelumnya telah ada asuransi konvensinal yang menggunakan sistem bunga. Dari situ para ulama bersilang pendapat tentang hukum asuransi, yakni: ${ }^{10}$

a. Pendapat pertama menyatakan bahwa semua jenis asu-ransi hukumnya haram;

b. Pendapat kedua menyatakan semua jenis asuransi hukumnya boleh;

c. Pendapat ketiga menyatakan hanya asuransi yang bersifat sosial yang dibolehkan, sedangkan jenis asuransi yang komersil/konsumtif dilarang;

d. Pendapat keempat menyatakan semua jenis asuransi hukumnya samar (syubhat).

Masjful Zuhdi menjelaskan bahwa pendapat pertama didukung oleh para ulama seperti Sayyid Sabiq (Penulis Figh Sunnah), Abdullah al-Qalqili (Mufti Yordania), Muhammad Yusuf al-Qardhawi (Penulis al-Halal wa Haram fi al-Islam) dan Muhammad Bakhit alMuth'i (Mufti Mesir). Mereka mengharamkan asuransi dengan alasan:

a. Asuransi sama dengan judi (gambling);

b. Dalam asuransi terdapat ketidakjelasan (uncertainty);

c. Asuransi mengandung unsur riba (rente);

d. Asuransi mengandung unsur eksploitasi; jika seseorang tidak melanjutkan pembayaran premi, maka ia dapat kehilangan hak klaim asuransi;

e. Premi yang dibayar peserta asuransi, dikelola dalam praktek yang berbau riba';

f. Asuransi termasuk akad sharf yakni jual beli secara tidak tunai;

\footnotetext{
${ }^{9}$ Murtadha Muthahari dan M. Baqir Ash-Shadr, Pengantar Ushul Figh dan Ushul Fiqh Perbandingan, terj. Satrio Pinandih dan Ahsin Muhammad (Jakarta: Pustaka Hidayah. 1993), hlm. 44-50.

${ }^{10}$ Masjfuk Zuhdi, Masail Fiqhiyah (Jakarta: CV. Haji Masagung. 1994), hlm. 134-135.
}

g. Hidup mati manusia telah dijadikan obyek bisnis, maka bertentangan dengan kehendak Tuhan Yang Maha Kuasa.

Pendapat kedua dikemukakan oleh Abdul Wahhab Khallaf, Mustafa Ahmad azZarqa (Guru Besar Hukum Islam Fakultas Syari'ah Universitas Syria), Muhammad Yusuf Musa (Guru Besar Hukum Islam Universitas (airo Mesir) dan Abdurrahman Isa (Penulis al-Muamalat al-Haditsah wa Ahkamuha). Mereka membolehkan asuransi dengan alasan berikut:

a. Dalam nash tidak tegas dilarang keharaman asuransi;

b. Prinsip pokok asuransi berdasar pada kesepakatan dan kesukarelaan (ittifaq wa 'antaradin);

c. Ada aspek saling tolong-menolong dan saling mengun-tungkan (ta'awun wa tasharruf);

d. Memiliki aspek yang menguntungkan kepentingan umum (maslahat fi al-ummah);

e. Mengandung model transaksi pembagian keuntungan berdasarkan prinsip bagi hasil (mudharabah atau profit and loss sharing);

f. Mengandung prinsip perserikatan modal dalam bentuk koperasi (syirkah ta'awuniyah);

g. Memiliki kesamaan dengan prinsip tabungan pensiun sejenis Taspen.

Pendapat ketiga dikemukakan leh Muhammad Abu Zahrah (Guru Besar Hukum Islam Universitas Cair Mesir), dengan alasan bahwa model asuransi sosial dibolehkan karena akan memiliki dampak positif kepada masyarakat, sedangkan model asuransi komersil/konsumtif akan berdampak kepada tumbuhnya praktek riba'.

Pendapat keempat menyatakan bahwa kedudukan hukum asuransi adalah syubhat, dikemukakan dalam Putusan Sidang Majelis Tarjih Muhammadiyah. Asuransi dikategorikan syubhat. karena ketidakjelasan pembagian keuntungan dan ketidaksebandingan polis yang didapat dengan premi yang harus dibayar merupakan unsur gharar dan maysyir dalam praktek asuransi konvensional Tetapi 
asuransi bisa dibolehkan jika bersifat darurat (emergency) dan menyangkut hajat hidup orang banyak (public needs).

Dari perbedaan pendapat di atas, tampak masalahnya tidak jauh berbeda dengan status bunga bank (bank interest) di bank konvensional. Tatkala muncul Asuransi Takaful sebagai instrumen lembaga asuransi syari’ah, maka asuransi takaful dapat menggantikan posisi asuransi konvensional yang cenderung menggunakan sistim bunga yang berbau riba, gharar dan maysyir.

Dapat dikatakan di sini bahwa asuransi syariah menggunakan Al-Quran dan sunnah nabi sebagai rujukannya memiliki sumber inspirasu dan inovasi yang tidak habis-habisnya dalam memberi kemaslahatan pada umat. Konsep dasar asuransi syariah terutama menggunakan sistem kafalah dan ta'awun yang akan terbebas dari ketidakpastian usaha di sektor asuransi asuransi syariah.

\section{Konsep Asuransi Syari'ah Menurut Taqiyyuddîn Al-Nabani \\ 1. Biografi Singkat Taqiyyuddîn Al-Nabani}

Syekh Taqiyyuddîn An Nabhani (19091977 M) adalah seorang qadhi (hakim), penyair, sasterawan dan salah seorang ulama terkemuka dalam Daulah Utsmaniyah. Nama penuhnya "Syekh Muhammad Taqiyyuddîn bin Ibrahim bin Musthafa bin Ismail bin Yusuf An Nabhani". la dilahirkan di daerah ljzim, Syekh An Nabhani dinisbahkan kepada kabilah Bani Nabhan yang termasuk orang Arab, penghuni padang sahara di Palestina. Mereka bermukim di daerah ljzim yang termasuk wilayah Haifa di Palestin Utara.

Syekh Taqiyyuddîn mendapat didikan ilmu syariah dan agama di rumah daripada ayah dan datuknya. Ayahnya seorang syekh yang faqih fid din (arif dalam agama) serta seorang pengajar ilmu-ilmu syari'ah di Kementerian Pendidikan Palestin. Datuknya telah mengajarkan hafalan Al-Quran sehingga beliau hafal Al-Quran seluruhnya sebelum baligh. Ibunya juga menguasai beberapa cabang ilmu syari'ah, yang diperolehnya dari ayahnya, Syekh Yusuf bin Ismail bin Yusuf An Nabhani. ${ }^{11}$

Di samping itu, Syekh Taqiyyuddîn juga mendapatkan pendidikannya di sekolah-sekolah negeri ketika beliau bersekolah di sekolah dasar di daerah ljzim. Pertumbuhan Syekh Taqiyyuddîn dalam suasana keagamaan yang kental seperti itu, ternyata mempunyai pengaruh yang besar dalam pembentukan kepribadian dan pandangan hidupnya. Beliau telah hafal Al-Quran seluruhnya dalam usia yang amat muda, yaitu di bawah usia 13 tahun. Kemudian Syekh Taqiyyuddîn berpindah ke sebuah sekolah di Akka untuk melanjutkan pendidikannya di sekolah menengah. Sebelum menamatkan sekolahnya di Akka, beliau telah bertolak ke Kaherah untuk meneruskan pendidikannya di Universitas al-Azhar, hasil dorongan datuknya, Syekh Yusuf An Nabhani. ${ }^{12}$

Syekh Taqiyyuddîn kemudian meneruskan pendidikannya di Tsanawiyah Al Azhar pada tahun 1928 dan pada tahun yang sama, beliau meraih ijazah dengan predikat sangat cemerlang. Lalu beliau melanjutkan pelajarannya di Kulliyah Darul Ulum yang saat itu merupakan cabang Al Azhar. Di samping itu, beliau banyak menghadiri halaqah-halaqah ilmiyah di Al Azhar yang diikuti oleh syekhsyekh Al Azhar, semisal Syekh Muhammad Al Hidlir Husain seperti yang pernah disarankan oleh datuknya. Hal itu dimungkinkan kerana sistem pengajaran lama Al Azhar membolehkannya. ${ }^{13}$

Meskipun Syekh Taqiyyuddîn menghimpun sistem Al Azhar lama dengan Darul Ulum, akan tetapi beliau tetap menampakkan keunggulan dan keistimewaan dalam kesungguhan dan ketekunan belajar. Beliau telah menarik perhatian kawan-kawan dan pensyarah-pensyarahnya kerana kecermat-

\footnotetext{
${ }^{11}$ Anonimous, Biografi Taqiyuddin An-Nabhani dalam http://ms.wikipedia.org/wiki/ Syekh_TaqiyuddinAn_Nabhani, diakses tanggal 28 Januari 2013.

${ }^{12}$ Ali Hasanah (Menteri Dalam negeri Yordania), Biografi Singkat Pendiri Hizbu Tahrir: Taqiyuddin AnNabhani dalam http://osdir.com/ml/culture.region.indonesia.ppi-india/2005-03/msgoo888.html, diakses tanggal 28 Januari 2013.

${ }^{13}$ Anonimous, The Biographical Skecth of Taqiyuddin An-Nabhani dalam http://www. goodreads. Com/ author/show/698279, diakses tanggal 28 Januari 2013.
} 
annya dalam berpikir dan kuatnya pendapat seta hujjah yang beliau lontarkan dalam perdebatan-perdebatan fikriyah, yang diselenggarakan oleh lembaga-lembaga ilmu yang ada saat itu di Kaherah dan di negeri-negeri Islam lainnya.

Syekh Taqiyyuddîn menamatkan kuliahnya di Darul Ulum pada tahun 1932 M. Pada tahun yang sama beliau menamatkan pula kuliahnya di Al Azhar Asy Syarif menurut sistem lama, di mana para mahasiswanya dapat memilih beberapa syekh Al Azhar dan menghadiri halaqah-halaqah mereka mengenai bahasa Arab, dan ilmu-ilmu syari'ah seperti figh, ushul figh, hadis, tafsir, tauhid (ilmu kalam) dan yang sebagainya, termasuk dalam bidang ekonomi Islam. ${ }^{14}$

Dalam forum-forum halaqah ilmiyah tersebut, al-Nabhani dikenali oleh kawan-kawan dan sahabat-sahabat terdekatnya dari kalangan Al Azhar sebagai seseorang dengan pemikiran yang genius, pendapat yang kukuh, pemahaman dan pemikiran yang mendalam, serta berkemampuan tinggi untuk menyakinkan orang dalam perdebatan-perdebatan dan perbincangan-perbincangan fikriyah. Demikian juga beliau sangatlah bersungguh-sungguh, tekun, dan bersemangat dalam memanfaatkan waktu guna menimba ilmu dan belajar.

Setelah menyelesaikan pendidikannya, Syekh Taqiyyuddîn kembali ke Palestin untuk kemudian bekerja di Kementerian Pendidikan Palestin sebagai seorang guru di sebuah sekolah menengah kerajaan di Haifa. Di samping itu, beliau juga mengajar di sebuah Madrasah Islamiyah di Haifa. Pada tahun 1940 M, Syekh Taqiyyuddîn diangkat sebagai Musyawir (pembantu qadi) dan beliau terus memegang jawatan ini hingga tahun $1945 \mathrm{M}$, yakni saat beliau dipindah ke Ramallah untuk menjadi qadi di Mahkamah Ramallah hingga tahun 1948. Setelah itu, beliau keluar dari Ramallah menuju Syam sebagai akibat jatuhnya Palestin ke tangan Yahudi. ${ }^{15}$

\footnotetext{
${ }^{14}$ Taqiyuddin An-Nabhani dalam al-Nidzamu alIqtishadi fi al-Islam dikutip dari situs http://e-syariah.net/artikel.asp?id=20, diakses tanggal 28 Januari 2013.

${ }^{15}$ Anonimous, Taqiyuddin An-Nabhani: The Palestinian Intellectual dalam http:// www. Yadim.com.-
}

Pada tahun 1948 M itu pula, sahabatnya Al Ustadz Anwar Al Khatib mengirim surat kepada beliau untuk memintanya kembali ke Palestin untuk diangkat sebagai qadi di Mahkamah Syar'iyyah Al Quds. Syekh Taqiyyuddîn mengabulkan permintaan itu dan kemudian beliau diangkat sebagai qadi di Mahkamah Syar'iyyah Al Quds pada tahun $1948 \mathrm{M}$. Pada tahun 1951 M, Syekh Taqiyyuddîn menziarahi kota Amman untuk menyampaikan ceramah-ceramahnya kepada para pelajar Madrasah Tsanawiyah di Kulliyah Ilmiyah Islamiyah. Hal ini terus berlangsung sehingga awal tahun $1953 \mathrm{M}$, ketika beliau mulai sibuk dalam Hizbut Tahrir yang telah beliau rintis antara tahun $1949 \mathrm{M}$ hingga 1953 M. Sejak remaja, Syekh Taqiyyuddîn sudah memulai kegiatan politiknya kerana pengaruh datuknya, Syekh Yusuf An Nabhani. Pengalaman itulah yang menghantarkannya mendirikan parti politik Islam, "Parti Hizbut Tahrir di Al Quds" pada tahun 1953 M. Syekh Taqiyyuddîn meninggal dunia pada tahun 1398 H/1977 M dan dikuburkan di Perkuburan Al Auza'i di Beyrut.

Syekh Taqiyyuddîn telah meninggalkan kitab-kitab penting yang dapat dianggap sebagai kekayaan pemikiran yang tidak ternilai harganya. Karya-karya ini menunjukkan bahwa Syekh Taqiyyuddîn An Nabhani merupakan seorang yang mempunyai pemikiran bijak dan beranalisis yang cermat. Karyakarya Syekh Taqiyyuddîn yang paling terkenal dan yang memuat pemikiran dan ijtihad beliau antara lain termasuk ribuan risalah (nasyrah) mengenai pemikiran, politik dan ekonomi, antara lain:
a. Nizhamul Islam;
b. Al-Takattul Al Hizbi;
c. Mahafim Hizbut Tahrir;
d. Al-Nizhamul Iqthishadi fi al-Islâm;
e. Al-Nizhamul ljtima'i fi al-Islâm;
f. Nizhamul Hukm fi al-Islâm;
g. Ad Dustur;
h. Muqaddimah Dustur;
i. Al-Dawlatul Islâmiyah;
j. Al-Syakhshiyyah Al-Islâmiyah (3 jilid);
k. Mafâhim Siyâsiyyah li Hizbit Tahrîr;

my/english/Ulama/UlamaFull.asp?Id=75, diakses pada tanggal 28 Januari 2013. 
I. Nazharat Siyâsiyyah li Hizbit Tahrîr;

m. Nida' Hâr;

n. Al-Khilâfah;

o. Aal-Tafkîr;

p. Al-Dusiyyah;

q. Sur'atul Bâdihah;

r. Nuqthatul Inthilâq;

s. Dukhûlul Mujtama';

t. Inqadzu Filisthin;

u. Risâlatul 'Arab;

v. Tasalluh Mishr;

w. Al-Ittifaqiyyah al-Tsana'iyyah Al-Mishriyyah al-Suriyyah wa al-Yamaniyyah;

x. Hallu Qadliyah Filisthin 'ala al-Tharîqah al-Amrikiyyah wal Inkiliziyyah;

y. Nazhariyatul Firagh al-Siyâsi Hawla Masyru' Ayzanhawar.

\section{Teori Asuransi Syari'ah Perspektif Taqi- yyuddîn Al-Nabani}

Namun dari perbedaan pendapat di atas, beberapa pendapat yang melarang asuransi lebih karena alasan-alasan yang normatif dan tekstualis. Jika demikian, syari'at Islam dianggap tidak mampu merespon perkembangan ekonomi modern. Akan lebih baik, jika memilih jalan tengah bahwa asuransi tetap dibolehkan selama masih berpegang kepada prinsip-prinsip syari'ah.

Taqiyyudin Al-Nabani dalam kitab alNidzamu al-lqtishâdi fi al-Islâm menjelaskan bahwa asuransi konvensional termasuk kategori akad yang batil. Sebaliknya, agar asuransi sesuai dengan nilai-nilai syari'at, maka diperlukan dua syarat berikut: Pertama, harus terpenuhinya segala ketentuan akad sebagaimana akad yang dibenarkan oleh syara'; Kedua, akad dalam asuransi harus memenuhi syarat bagi sahnya akad jaminan (dhaman). ${ }^{16}$

Suatu akad akan dinilai sah oleh syari'at jika akadnya itu berlangsung secara sah, baik menyangkut barang maupun jasa. Akad terjadi menyangkut barang, baik dengan imbalan seperti dalam akad jual beli, atau tanpa imbalan seperti dalam hibah atau hadiah.

\footnotetext{
${ }^{16}$ Taqiyuddin An-Nabhani dalam al-Nidzamu allqtishadi fi al-Islam dikutip dari situs http://e-syariah.net/artikel.asp?id=20, diakses tanggal 28 Januari 2013.
}

Akad dapat pula terjadi pada jasa, baik dengan imbalan seperti dalam perburuhan (ijarah) atau tanpa imbalan seperti dalam akad pinjaman ('ariyah).

Dilihat dan kategori tersebut, menurut Taqiyudin Al-Nabani akad asuransi tidaklah termasuk dalam akad, baik itu menyangkut barang maupun jasa. Karena dalam faktanya, akad asuransi itu berkaitan dengan perjanjian atas jaminan pertanggungan. Janji ini tidak dapat dianggap barang, karena dzatnya tidak bisa dinikmati serta dimanfaatkan. Tidak bisa juga dianggap jasa, karena tidak ada yang bisa memanfaatkan janji tersebut, baik secara langsung maupun tidak langsung.

Adapun didapatnya sejumlah uang berdasarkan janji kesediaan menanggung itu, tetap tidak dapat merubah fakta bahwa janji itu bukanlah jasa, karena uang pertanggungan itu hanyalah merupakan akibat dari kesepakatan yang telah dilakukan sebelumnya. Dari situlah, Taqiyyudîn Al-Nabani menyatakan asuransi tidak memenuhi syarat agar bisa disebut akad yang sah. Pendapat ini didukung pula oleh Khalid Abdul Rahman Ahmad dalam kitabnya al-Tafkir al-lqtishady fi al-Islam.

Taqiyyudin Al-Nabani juga menjelaskan bahwa jaminan (dhaman) adalah pemindahan harta pihak penjamin kepada pihak yang dijamin untuk menunaikan suatu kewajiban. Oleh karena itu, pemindahan harta seseorang kepada pihak lain itu disyaratkan harus ada penjamin (dhamin), ada yang dijamin (madhmun 'anhu) dan ada yang menerima jaminan (madhmun lahu). Agar jaminan itu sah, disyaratkan terjadi dalam perkara penunaian hak harta yang benar-benar wajib dipenuhi oleh yang dijamin. Sebagai contoh, jika seseorang memiliki utang yang akan jatuh tempo, atau sejenis garansi terhadap barang dan sebagainya, dan yang dijamin tidak mendapatkan apa-apa, maka tidak terjadi pemindahan harta. Jika tidak ada kewajiban untuk menunaikan oleh pihak yang dijamin, maka tidak wajib pula ditunaikan oleh pihak penjamin. $^{17}$

\footnotetext{
${ }^{17}$ Taqiyyûdin al-Nabhani menyandarkan pendapatnya kepada hadits Nabi tentang tanggungan hutang-piutang orang yang telah meninggal dunia, yakni
} 
Berdasarkan pendapat tersebut, akad jaminan pada asuransi konvensional tidaklah memenuhi keseluruhan syarat bagi sahnya sebuah akad jaminan yang disahkan oleh syari'at. Dalam asuransi konvensional memang seolah-olah terdapat pihak penjamin yakni perusahaan asuransi, tetapi pihak yang dijamin, yakni peserta dan ahli waris yang menerima jaminan bergantung kepada jenis asuransi.

Misalnya saja, dalam asuransi jiwa, penerima jaminan adalah ahli waris. Akan tetapi dalam asuransi kecelakaan, kebakaran dan angkutan, yang menerima jaminan adalah peserta itu sendiri. Jadi, tidak ada pemindahan hak seseorang kepada orang lain. Perusahaan asuransi sendiri kenyataannya tidak menjaminkan assetnya kepada seseorang untuk menu-naikan kewajiban pihak tertanggung (madhmun 'anhu). Atas dasar itu, maka perusahaan asuransi tidak bisa disebut pihak penjarnin (dhamin).

Pada prakteknya di Indonesia, dalam hal pengelolaan dana peserta asuransi oleh kantor asuranasi dilakukan dengan cara bagi hasil dalam bentuk:

a. Mudharabah yakni suatu bentuk pembiayaan yang diberikan oleh bank kepada debitur untuk keperluan modal kerja atau investasi atas dasar kepercayaan (trustee). Bank Syari'ah tidak turut campur dalam manejemen usaha debitur. Keuntungan yang kemudian diperoleh dari hasil usaha tersebut dibagihasilkan antara bank dan debitur berdasarkan akad (kesepakatan). Apabila rugi, selu-

hadits dari Abu Darda yang berunyi: "Rasulullah SAW pernah tidak bersedia menshalatkan (mayat) seorang laki-laki yang mempunyai hutang (semasa hidupnya). Rasulullah SAW. disodori jenasahnya (untuk dishalatkan), kemudian beliau bersabda: "Apakah la mempunyai hutang?" Mereka menjawab: "Benar, yaitu dua dinar." Kemudian beliau bersabda: "Shalatkan sahabat kalian.". Dipertegas pula dengan hadits Nabi dari Abu Qatadah al-Anshari bahwa: "Biarkan hutangnya menjadi tanggunganku, ya Rasulullah. Maka beliau lalu mau menshalatkannya. Ketika Allah telah menaklukkan berbagai negeri di bawah kekuasaan Rasulullah SAW, beliau bersabda: "Aku lebih utama bagi setiap mukmin dan diri mereka sendiri. Maka barang siapa yang meninggalkan hutang, akulah yang akan melunasinya, dan barang siapa yang meninggalkan warisan maka harta warisan itu bagi pewarisnya". Lihat dalam situs http://e-syariah.net/artikel.asp?id=20, diakses tanggal 28 Januari 2013. ruh kerugian "financial" ditanggung oleh bank (pada hakekatnya debitur juga menanggung "kerugian", dari sisi waktu, tenaga, pikiran dan sebagainya);

b. Musyarakah yakni suatu bentuk pembiayaan yang diberikan oleh bank kepada debitur untuk modal kerja atau investasi atas dasar syirkah (persekutuan usaha/join venture). Bank berhak ikut serta dalam manajemen usaha debitur. Keuntungan maupun kerugian dari usaha tersebut, diterima dan ditanggung bersama oleh bank dan debitur secara proposional sesuai dengan akad. Joint Venture ini umumnya merupakan produk usaha patungan (bagi hasil) melalui sebuah konsorsium usaha di Lembaga Keuangan Konvensional (LKK) untuk mengelola pertanian secara bersama-sama.

\section{Konsep Asuransi Konvensional Menu- rut Thomas Robert Maltus}

1. Biografi Singkat Thomas Robert Maltus Thomas Robert Malthus (Februari 1766 M - 23 Desember 1834 M), yang biasanya dikenal sebagai Thomas Malthus, meskipun ia lebih suka dipanggil dengan "Robert Malthus", adalah seorang pakar demografi Inggris dan ekonom politk yang paling terkenal karena pandangannya yang pesimistik namun sangat berpengaruh tentang pertambahan penduduk. ${ }^{18}$

Malthus dilahirkan dalam sebuah keluarga yang kaya. Ayahnya, Daniel, adalah sahabat pribadi filsuf dan skeptik David Hume dan kenalan dari Jean-Jacques Rousseau. Malthus muda dididik di rumah hingga ia diterima di Jesus College, Cambridge pada 1784. Di sana ia belajar banyak pokok pelajaran dan memperoleh penghargaan dalam deklamasi Inggris, bahasa Latin dan Yunani. Mata pelajaran utamanya adalah matematika. la memperoleh gelar magister pada 1791 $M$ dan terpilih menjadi fellow dari Jesus College dua tahun kemudian. Pada 1797 M, ia

\footnotetext{
${ }^{18}$ Samuel Hollander, The Economics of Thomas Robert Malthus (t.t.: University of Toronto Press. 1997), hlm. 89.
} 
dihabiskan dan menjadi pendeta Anglikan di desa. ${ }^{19}$

Malthus menikah pada tahun $1804 \mathrm{M}$, ia dan istrinya mempunyai tiga orang anak. Pada $1805 \mathrm{M}$ ia menjadi profesor Britania pertama dalam bidang ekonomi politik di East India Company College di Haileybury di Hertfordshire. Siswa-siswanya menyapanya dengan sebutan kesayangan "Pop" (yang dapat berarti "papa") "Populasi" Malthus. Pada $1818 \mathrm{M}$, ia terpilih menjadi Fellow dari Perhimpunan Kerajaan. ${ }^{20}$

Malthus menolak dibuat fotonya hingga tahun 1833 M karena ia merasa malu karena sumbing. Masalah ini kemudian diperbaiki lewat operasi, dan Malthus dianggap sangat tampan. Sumbingnya juga meluas hingga ke dalam mulutnya yang mempengaruhi bicaranya. Cacat ini adalah bawaan sejak lahir yang cukup lazim di lingkungan keluarganya. Malthus dikebumikan di Bath Abbey di Inggris.

Pandangan-pandangan T.R. Malthus umumnya dikembangkan sebagai reaksi terhadap pandangan-pandangan yang optimistik dari ayahnya dan rekan-rekannya, terutama Rousseau. Esai Malthus juga dibuat sebagai tanggapan terhadap pandangan-pandangan Marquis de Condorcet. Dalam An Essay on the Principle of Population (Sebuah Esai tentang Prinsip mengenai Kependudukan), yang pertama kali diterbitkan pada $1798 \mathrm{M}$, Malthus membuat ramalan yang terkenal bahwa jumlah populasi akan mengalahkan pasokan makanan, yang menyebabkan berkurangnya jumlah makanan per orang. ${ }^{21}$

Dalam pemikiran ekonomi, ia bahkan meramalkan secara spesifik bahwa hal ini pasti akan terjadi pada pertengahan abad ke19 , sebuah ramalan yang gagal karena beberapa alasan, termasuk penggunaan analisis statisnya, yang memperhitungkan kecenderungan-kecenderungan yang mutakhir dan

\footnotetext{
${ }^{19}$ Eric B. Ross. The Malthus Factor: population, poverty, and politics in capitalist development. (London: Zed Books. 1998), hlm. 112.

${ }^{20} \mathrm{Karl} \mathrm{E}$ Case and Ray C Fair, Principles of Economics (t.t.: Prentice-Hall. 1999), hlm. 790.

${ }^{21}$ Anonimous, The Biography of Thomas Robert Maltus dalam http://id.wikipedia. org/wiki/ThomasMalthus, diakses tanggal 10 Februari 2013.
}

memproyeksikannya secara tidak terbatas ke masa depan, yang hampir selalu gagal untuk sistem yang kompleks.

\section{Teori Asuransi Perspektif Thomas Ro- bert Maltus}

Konsep asuransi di Barat sesungguhnya mengadopsi sejarah ekonomi yang dikenal sejak jaman sebelum Masehi, di mana manusia pada masa itu telah menyelamatkan jiwanya dari berbagai ancaman, antara lain kekurangan bahan makanan. Salah satu cerita mengenai kekurangan bahan makanan terjadi pada jaman Mesir Kuno semasa Raja Firaun berkuasa.

Pada suatu hari, sang raja bermimpi yang diartikan oleh Nabi Yusuf bahwa selama 7 tahun negeri Mesir akan mengalami panen yang berlimpah dan kemudian diikuti oleh masa paceklik selama 7 tahun berikutnya. Untuk berjaga-jaga terhadap bencana kelaparan tersebut Raja Firaun mengikuti saran Nabi Yusuf dengan menyisihkan sebagian dari hasil panen pada 7 tahun pertama sebagai cadangan bahan makanan pada masa paceklik. Dengan demikian pada masa 7 tahun paceklik rakyat Mesir terhindar dari risiko bencana kelaparan hebat yang melanda seluruh negeri.

Pada tahun $2000 \mathrm{M}$ sebelum masehi para saudagar dan aktor di Italia membentuk Collegia Tennirium, yaitu semacam lembaga asuransi yang bertujuan membantu para janda dan anak-anak yatim dari para anggota yang meninggal. Perkumpulan yang serupa yaitu Collegia Nititum, yang kemudian berdiri dengan keanggotakan para budak belian yang diperbantukan pada ketentaraan kerajaan Romawi. ${ }^{22}$

Setiap anggota mengumpulkan sejumlah iuran dan bila salah seorang anggota mengalami nasib sial (unfortunate) maka biaya pemakamannya akan dibayar oleh anggota yang bernasib baik (fortunate) dengan menggunakan dana yang telah dikumpulkan sebelumnya. Perkumpulan semacam ini merupakan salah satu konsep awal timbulnya

\footnotetext{
${ }^{22}$ Anonimous, Sejarah Asuransi dalam http://informasi-asuransi.blogspot.com/, diakses tanggal 10 Februari 2013.
} 
asuransi, yaitu orang-orang yang beruntung atau bernasib baik membantu orang-orang yang tidak beruntung. Dari situlah ia memiliki ide untuk melahirkan konsep asuransi.

Berkenaan dengan teori asuransi, Thomas Robert Maltus menjelaskan bahwa Pada reasuransi konvensional, kontrak antara kedua belah pihak dimana insurer memberlakukan diri sebagai pihak yang dijamin membayarkan premi asuransi kepada pihak perusahaan reasuransi. Terjadi transfer risiko dari reasuransi kepada insurer. Pada reasuransi syariah, manakala kumpulan orang-orang setuju untuk membantu satu sama lain, menjaminkan satu sama lain dan saling bekerja sama melalui donasi beberapa dana tabarru. Pada akad asuransi konvensional adalah jasa penjualan dengan bunga.

Selanjutnya, Thomas Robert Maltus menjelaskan bahwa dalam hal asuransi konvensional tercermin adanya peran dan fungsi individu untuk saling membangtu secara kolektif dalam hal pertangungan. Pandangan ini dikenal dengan istilah teori fungsional ekonomi yang mencakup atas: ${ }^{23}$

\section{a. Fungsi Anggaran (Budgetair)}

Sebagai sumber pendapatan negara, asuransi berfungsi untuk membiayai pengeluaran-pengeluaran negara. Untuk menjalankan tugas-tugas rutin negara dan melaksanakan pembangunan, negara membutuhkan biaya. Biaya ini dapat diperoleh dari penerimaan pahak. Dewasa ini pajak digunakan untuk pembiayaan rutin seperti belanja pegawai, belanja barang, pemeliharaan, dan lain sebagainya. Untuk pembiayaan pembangunan, uang dikeluarkan dari tabungan pemerintah, yakni penerimaan dalam negeri dikurangi pengeluaran rutin. Tabungan pemerintah ini dari tahun ke tahun harus ditingkatkan sesuai kebutuhan pembiayaan pembangunan yang semakin meningkat dan ini terutama diharapkan dari sektor pajak.

\footnotetext{
${ }^{23}$ Pendapat T.R. Maltus yang dikutip oleh Sommerfeld Ray M., Anderson Herschel M., \& Brock Horace dalam tulisan P. J. A. Adriani dan Rochmat Soemitro tentang Prinsip Operasional Asuransi dipublikasikan dalam http://id.wikipedia.org/ wiki/Pajak\&asuransi, diakses tanggal 10 Februari 2013.
}

\section{b. Fungsi Mengatur (regulerend)}

Pemerintah dapat pula mengatur pertumbuhan ekonomi melalui kebijak-sanaan asuransi. Dengan fungsi mengatur, asuransi bisa digunakan sebagai alat untuk mencapai tujuan ekonomi. Contohnya untuk menggiring penanaman modal, baik dalam negeri maupun luar negeri, diberikan berbagai macam fasilitas asuransi. Untuk melindungi sektor produksi dalam negeri, pemerintah menetapkan bea masuk yang tinggi untuk produk luar negeri yang diimbangi dengan adanya penawaran jasa asuransi investasi.

\section{c. Fungsi Stabilitas}

Dengan adanya asuransi, pemerintah memiliki dana untuk menjalankan kebijakan yang berhubungan dengan stabilitas harga sehingga inflasi dapat dikendalikan, Hal ini bisa dilakukan antara lain dengan jalan mengatur peredaran uang di masyarakat, penawaran jasa asuransi, penggunaan asuransi yang efektif dan efesien. Dengan demikian, asuransi dapat menjaga stabilitas kepentingan-kepentingan sosial

\section{d. Fungsi Redistribusi Pendapatan}

Asuransi yang disediakan oleh negara akan digunakan untuk membiayai semua kepentingan masyarakat dan pelaku usaha, termasuk juga untuk membiayai pembangunan sehingga dapat membuka kesempatan kerja, yang pada akhirnya akan dapat meningkatkan pendapatan masyarakat. Oleh karena itu, tabungan dana asuransi milik masyarakat dapat dipergunakan untuk menopang dana pembangunan negara.

Di samping itu, menurut Thomas Robert Maltus, asuransi juga memiliki kelayakan bagi penguatan sektor perekonomian masyarakat. Teori akuntabiltas (accountability theory) digunakan untuk melihat asuransi sebagai salah satu instrumen ekonomi berdasarkan kepada pendapat para ekonom, antara lain:

a. Asuransi terkait dengan asas pemungutan yang mencakup atas:

1) Asas Equality (asas keseimbangan dengan kemampuan atau asas keadilan): penyediaan asuransi yang dilaku- 
kan oleh negara harus sesuai dengan kemampuan dan penghasilan masyarakat. Negara tidak boleh bertindak diskriminatif terhadap masyarakat.

2) Asas Certainty (asas kepastian hukum): semua praktek asuransi harus berdasarkan UU, sehingga bagi yang melanggar akan dapat dikenai sanksi hukum.

3) Asas Convinience of Payment (asas penarikan dan pembayaran asuransi yang tepat waktu atau asas kesenangan): asuransi harus dibayar tepat waktu bagi peserta, dan perusahaan pun harus membayar klaim asuransi tepat waktu pula.

4) Asas Effeciency (asas efesien atau asas ekonomis): biaya asuransi diusahakan sehemat mungkin, jangan sampai terjadi biaya pembayaran klaim (polis) lebih besar dari hasil penarikan (pre$\mathrm{mi})$.

b. Tujuan asuransi hendaknya mempertimbangkan asas kepatutan, yakni:

1) Asas daya pikul: besar kecilnya asuransi yang dipungut harus berdasarkan besar kecilnya penghasilan masyarakat. Semakin tinggi penghasilan maka semakin tinggi beban asuransi yang harus dibayarkan.

2) Asas manfaat: asuransi yang ditawarkan kepada masyarakat hendaknya ditujukan untuk kegiatan-kegiatan ekonomi yang memberi manfaat bagi kepentingan umum.

3) Asas kesejahteraan: asuransi yang ditawarkan kepada masyarakat dapat ditujukan untuk meningkatkan kesejahteraan rakyat.

4) Asas kesamaan: dalam kondisi yang sama antara peserta asuransi yang satu dengan yang lainnya harus dikenakan pajak dan administrasi dalam jumlah yang sama (diperlakukan sama).

5) Asas beban yang sekecil-kecilnya: pembayaran klaim (polis) diusahakan sekecil-kecilnya (serendah-rendahnya) jika dibandinglan sengan nilai obyek asuransi, sehingga tidak memberatkan para pengelola perusahaan asuransi. c. Dalam hal penawaran jasa asuransi kepada masyarakat hendaknya mempertimbangkan asas penawaran yang mencakup atas:

1) Asas politik uang: asuransi yang ditawarkan kepada masyarakat jumlahnya terjangkau sehingga dapat membiayai atau mendorong semua kegiatan ekonomi riil.

2) Asas ekonomi: penentuan jumlah polis asuransi harus tepat waktu. Misalnya: asuransi kecelakaan.

3) Asas keadilan yaitu penarikan dan pembayaran asuransi berlaku secara umum tanpa diskriminasi, untuk kondisi yang sama diperlakukan sama pula.

4) Asas administrasi: menyangkut masalah kepastian asuransi (kapan, dimana harus membayar asuransi), tingkat keluwesan penagihan (bagaimana cara membayarnya) dan besarnya biaya premi dan polis.

5) Asas yuridis segala penawrn asuransi harus berdasarkan Undang-Undang.

Kaitannya dengan kebijakan politik ekonomi suatu negara, Thomas Robert Maltus tampaknya menyandarkan teori politik ekonomi di bidang asuransi setara dengan kebijakan atas pajak. Agar negara dapat memberikan jasa asuransi kepada warganya atau kepada orang pribadi atau badan lain yang bukan warganya, tetapi mempunyai keterkaitan dengan negara tersebut, tentu saja harus ada ketentuan-ketentuan yang mengaturnya. Contohnya, dalam sistem hukum Eropa, dinyatakan bahwa asuransi diberikan untuk semua jenis pertanggungan resiko antara lain pendidikan, jiwa, kecelakaan, kendaraan bermotor dan lain-lain.

Ada beberapa asas yang dapat digunakan oleh negara sebagai asas dalam menentukan wewenangnya untuk mengatur masalah asuransi, khususnya untuk menawarkan asuransi jaminan. Asas utama yang paling sering digunakan oleh negara sebagai landasan untuk menawarkan asuransi, antara lain:

a. Asas domisili

Asas tersebut pula disebut juga asas kependudukan (domicile/residence principle), 
berdasarkan asas ini negara akan menawarkan asuransi kepada pribadi atau lembaga, apabila untuk kepentingan asuransi, orang pribadi tersebut merupakan penduduk (resident) atau berdomisili di negara itu atau apabila badan yang bersangkutan berkedudukan di negara itu. Dalam kaitan ini, tidak dipersoalkan dari mana penghasilan yang akan dikenai asuransi itu berasal. Itulah sebabnya bagi negara yang menganut asas ini, dalam sistem asuransi terhadap penduduknya akan menggabungkan asas domisili (kependudukan) dengan konsep penawaran asuransi kepada individu atau lembaga baik yang diperoleh di dalam negeri maupun yang diperoleh dari luar negeri (world-wide income concept);

\section{b. Asas sumber}

Negara yang menganut asas sumber penawaran asuransi atas kepada pribadi atau lembaga hanya apabila tingkat penghasilan yang diperoleh pribadi atau lembaga yang bersangkutan terkait dengan sumber-sumber yang berada di negara itu. Dalam asas ini, tidak menjadi persoalan mengenai siapa dan apa status dari orang atau badan yang memperoleh penghasilan tersebut sebab yang menjadi landasan penawaran asuransi adalah nilai investasi asuransi yang timbul atau berasal dari negara itu. Contoh: Tenaga kerja asing bekerja di Indonesia maka dari penghasilan yang didapat di Indonesia akan ditawari asuransi jasa tenaga kerja (JAMSOSTEK) oleh pemerintah Indonesia;

c. Asas kebangsaan/asas nasionalitas/asas kewarganegaraan (nationality/citizenship principle).

Dalam asas ini, yang menjadi landasan penawaran asuransi adalah status kewarganegaraan dari orang atau badan yang memperoleh penghasilan. Berdasarkan asas ini, tidaklah menjadi persoalan dari mana sumber penawaran asuransi itu berasal. Seperti halnya dalam asas domisili, sistem penawaran asuransi berdasarkan asas nasionalitas ini dilakukan dengan cara menggabungkan asas nasionalitas dengan konsep penawaran atas world wide income.
Dalam asuransi, terdapat beberapa perbedaan prinsipil antara asas domisili atau kependudukan dan asas nasionalitas atau kewarganegaraan di satu pihak, dengan asas sumber di pihak lainnya.

1) Pada kedua asas yang disebut pertama, kriteria yang dijadikan landasan kewenangan negara untuk menawarkan asuransi adalah status individu atau lembaga asuransi, yaitu apakah yang bersangkutan berstatus sebagai penduduk atau berdomisili (dalam asas domisili) atau berstatus sebagai warga negara (dalam asas nasionalitas). Di sini, asal muasal asuransi tidaklah begitu penting. Sementara itu, pada asas sumber, yang menjadi landasannya adalah dana yang diambil dari negara. Status dari orang atau badan yang memperoleh jasa asuransi tidak begitu penting;

2) Pada kedua asas yang disebut pertama, asuransi akan dikenakan terhadap setiap individu dan lembaga di mana saja (world-wide income), sedangkan pada asas sumber, asuransi yang ditawrakan hanya terbatas pada tingkat penghasilan-penghasilan individu dan lembaga dan kemapuan membayarnya dari sumber-sumber yang ada di negara yang bersangkutan.

Kebanyakan negara, tidak hanya mengadopsi salah satu asas saja, tetapi mengadopsi lebih dari satu asas, bisa gabungan asas domisili dengan asas sumber, gabungan asas nasionalitas dengan asas dan fungsi asuransi, bahkan bisa gabungan ketiganya sekaligus. Oleh karena itu, prinsip utama asuransi konvensional sesungguhnya berbasis pada ekonomi pasar sosial dan sistem ekonomi negara.

\section{E. Penutup}

Berdasarkan kepada uraian di atas dapat disimpulkan di sini bahwa asuransi merupakan suatu perjanjian antara dua pihak atau lebih; pihak penanggung mengikatkan diri kepada tertanggung dengan menerima sejumlah uang premi asuransi untuk memberikan penggantian kepada tertanggung karena kerugian, kerusakan atau kehilangan 
keuntungan atau tanggung jawab hukum kepada pihak ketiga yang timbul dari peristiwa yang tidak pasti untuk memberikan suatu pembayaran didasarkan atas meninggalnya atau hidupnya seseorang yang dipertanggungkan. Dalam Islam, asuransi didefinisikan sebagai sebuah usaha saling melindungi dan tolong menolong di antara sejumlah orang melalui investasi dalam bentuk aset dan/atau tabarru' yang memberikan pola pengembalian untuk menghadapi risiko tertentu melalui akad yang sesuai dengan syariah.

Dalam hal ini, perbedaan antara kedudukan asuransi dalam teori ekonomi Islam menurut Taqiyyuddîn Al-Nabani dan teori ekonomi konvensional menurut Thomas Robert Maltus di atas sesungguhnya telah diadopsi oleh masyarakat modern. Namun jika dilihat dari sisi keuntungan atau manfaatnya jelas asuransi syari'ah lebih besar manfaatnya dari pada kerugian/madharatnya. Karenanya, kendati asuransi tidak jelas disebutkan dan dijelaskan di dalam nash, tetapi secara hukum kita dibolehkan memanfaatkan jasa asuransi. Oleh karena itu, bagi umat muslim hendaknya berpedoman kepada prinsip-prinsip muamalah yang dibenarkan secara syari'at. Dengan kata lain, kita hanya dibenarkan memanfaatkan jasa asuransi yang dalam prinsip dan operasionalnya menggunakan prinsip-prinsip syari’ah.

\section{Daftar Pustaka}

Anonimous, Taqiyyuddîn Al-Nabani: The Palestinian Intellectual dalam http:// www. yadim.com.my/english/Ulama/UlamaFull .asp?Id=75, diakses tanggal 20 Januari 2014.

, Biografi Taqiyyuddîn Al-Nabani dalam http://ms.wikipedia.org/ wiki/Syekh_Taqiyyuddîn_An_Nabhani, diakses tanggal 20 Januari 2014.

, The Biography of Thomas Robert Maltus dalam http://id.wikipedia. Org/wiki/Thomas_Malthus, diakses tanggal 10 Februari 2014.

, Sejarah Asuransi dalam http://informasi-asuransi.blogspot.com/.
A. Djazuli dan Yadi Janwari. 2002. Lembagalembaga Perekonomian Umat. Jakarta: Rajawali Press.

Al-Nabani Taqiyyuddîn, al-Nidzamu al-lqtishâdi fi al-Islâm dikutip dari situs http://esyariah.net/artikel.asp?id=20, diakses tanggal 10 Februari 2014.

al-Tafkir al-lqtishâdy fi al-Islâm Lihat dalam situs http://e-syariah.net/artikel.asp?id=20, diakses tanggal 10 Februari 2014.

As-Syafi'i, Ahmad bin Idris. 1989. Figh al-Syafi'iyah (Terj) (Jakarta: CV. Karya Indah.

Case, Karl E. \& Fair, Ray C. 1999. Principles of Economics. t.t.: Prentice-Hall.

Hasanah, Ali. (Menteri Dalam negeri Yordania), Biografi Singkat Pendiri Hizbu Tahrir: Taqiyyuddîn Al-Nabani dalam http://osdir.com/ml/culture.region. indonesia.ppi-india/20053/msg00888.html, diakses tanggal 10 Februari 2014.

Hassan, M. Ali. 1997. Masail Fighiyah: Zakat, Pajak, Asuransi dan Lembaga Keuangan. Jakarta: PT. Raja Grafindo.

Hollander, Samuel. 1997. The Economics of Thomas Robert Malthus. t.t.: University of Toronto Press.

Janwari, Yadi. 2000. Diktat Perkuliahan Asuransi Takaful. Bandung: Fakultas Syari'ah IAIN SGD.

Murtadha Muthahari dan M. Baqir AshShadr. 1993. Pengantar Ushul Figh dan Ushul Fiqh Perbandingan, terj. Satrio Pinandih dan Ahsin Muhammad Jakarta: Pustaka Hidayah.

Prodjodikoro, Wirjono. 1972. Hukum Asuransi di Indonesia. Jakarta: PT. Pembimbing Masa.

Ross, Eric B. 1998. The Malthus Factor: population, poverty, and politics in capitalist development. Londong: Zed Books.

Sommerfeld Ray M., Anderson Herschel M., \& Brock Horace dalam tulisan P. J. A. Adriani dan Rochmat Soemitro dipublikasikan dalam http://id.wikipedia. org/ wiki/Pajak\&asuransi, diakses tanggal 10 Februari 2014.

Zadjuli, Suroso Imam. Kelembagaan Ekonomi Islam Dalam Perspektif Islam: Kajian Kritis Terhadap Kelembagaan Konvensional, 
makalah dalam "Seminar dan Lokakarya Kurikulum dan Silabus Ekonomi Islam" untuk Program Pascasarjana Universitas Islam Negeri (UIN) Syarif Hidayatullah Jakarta. Juni 2003.
Zuhaili, Wahbah. 1986. Ushul Fiqh Al-Islami. Damaskus: Dar al-Fikr.

Zuhdi, Masjfuk. 1994. Masail Fighiyah. Jakarta: CV. Haji Masagung. 